Ind. Health, 1973, 11, 85.

\title{
EFFECT OF LOW LEAD CONCENTRATION ON HUMAN BODY
}

\author{
Kazuo SAITO, Toshio SATO, Yuji SATO and Kozo NIIZUMA \\ Department of Hygiene and Preventive Medicine, Hokkaido University \\ School of Medicine, Kita 15, Nishi 7, Sapporo and Sapporo City \\ Institute of Public Health, Minami 9, Nishi 7, Sapporo
}

(Received May 17, 1973)

\begin{abstract}
The concentration of lead in the whole blood of 203 traffic policemen, whose mean value and standard error of lead content in blood showed $9.60 \pm 0.22(95 \%$ upper limit of 13.7$) \mu \mathrm{g} / 100 \mathrm{ml}$ of blood, differed from the large in scale of cities at low lead concentration less than $10 \mu \mathrm{g} / \mathrm{m}^{3}$ of air.

In comparison between traffic policemen and lead workers, the latter were significantly higher at the lead content and ALAD activity in erythrocytes than those of the former. The correlation between ALAD activity in erythrocytes and lead concentration in blood was found in both workers, but among the samples under $15.0 \mu \mathrm{g}$ $\mathrm{pb} / 100 \mathrm{ml}$ of blood in traffic policemen was not observed significant decrease of ALAD activity and any correlation.
\end{abstract}

Lead is ubiquitous in our industrial and everyday life. Recently, much attention has been paid to air pollution caused by lead in automobile exhaust gases in Japan and there is undoubtedly interest in the amount of lead in the air. The effect of atmospheric lead on the inhabitants has become an important problem. The amount of lead in the air is closely connected with gasoline consumption ${ }^{1)}$ and it is also much in the densely populated cities in Japan. ${ }^{2)}$

Goldsmith $e t a l .{ }^{3)}$ reported that the lead concentration in the blood of inhabitants correlated logarithmically with the lead concentration in the air and that the latter played an important role in the increase of lead in human bodies.

Hokkaido is now one of the least environmentally polluted areas in Japan, but it is predicted that Hokkaido will also become a polluted area in 5 years as other districts in Japan have done. Hokkaido has the characteristics of a bigger undeveloped and the more sparsely populated area than Honshu (main land of Japan), but nowadays it is gradually under-going developement. In this paper, lead levels in the blood of inhabitants in Hokkaido were examined to learn the present state polluted by atmospheric lead and were compared with those of other districts. Herenberg et al.45) reported that $\delta$-aminolevulinic acid dehydrase activity in red blood cells (ALAD) was inhibited by lead under normal urban conditions and that this enzyme was an excellent measure of lead exposure. Haeger-Aronsen ${ }^{6)}$ also 


\section{K. SAITO, T. SATO, Y. SATO AND K. NIIZUMA}

reported on the correlation between lead content in blood and ALAD recently. The authors discussed also a relationship of lead concentration in blood ranged in normal values to ALAD and the limit in this paper.

\section{MAterial AND Methods}

Two hundred three traffic policemen on patrol by car, aged from 21 to 49 years, who belong to the Hokkaido Police Office and 19 workers, aged from 19 to 28 years, exposed to inorganic lead dust $(68 \%$ of $\mathrm{PbO})$ at a ceramics producing company, were inspected on the specific gravity of whole blood, microhematocrit, lead concentration in blood and $\delta$-aminolevulinic acid dehydrase activity in erythrocytes (ALAD). One hundred fifteen of the 203 policemen were from a big city, 57 from the middle sized cities and 31 from the small cities. None of them had worked in other districts, so that, they had their own permanent area for patrol. The big cities above mentioned have above 1,000,000 in population, the middle sized cities 50,000 up to 200,000 and the small sized cities under 50,000. That is, in this survey the big city is Sapporo, the middle cities are Otaru, Muroran, Tomakomai, Iwamizawa, Ebetsu, Chitose, Takikawa and Yubari, and the small cities are Yoichi, Kuttyan, Datemonbetsu, Shizunai, Urakawa, Kadobetsu, Akabira, Ashibetsu, Kuriyama, Mikasa, Bibai and Sunagawa.

Twelve milliliters of blood for examination was withdrawn from the Vena mediana cubiti by syringe. The specific gravity of whole blood was measured with the method of cupric sulfate, and hematocrit reading was measured with micromethod, in which samples in micro-glass tube were spun for 5 minutes at $11,000 \mathrm{rpm}$, and the packed red cells were measured with the graduated table chart. The activity of ALAD in erythrocytes was determined according to Mauzerall and Granick ${ }^{7}$, and calculated by the following method. Original solution which $100 \mathrm{mg}$ of $\delta$-aminolevulinic acid (ALA) was soluted to $14 \mathrm{ml}$ of $0.05 \mathrm{M}$ phosphate buffer, was used to the measurement of ALAD activity. Zero point four milliliters of the blood samples were poured into $7 \mathrm{ml}$ glass test tubes within $4 \mathrm{hr}$ after its collection and storaged for about 3 weeks at $-76^{\circ} \mathrm{C}$ in an icebox for combining destruction of blood corpuscle. Zero point two milliliters of these blood samples taken out with micropipet, and $0.1 \mathrm{ml}$ of phosphate buffer ( $\mathrm{pH} 7.4$ ) and $0.1 \mathrm{ml}$ of the above ALA solution were mixed in glass test tube. Then it was shaken for $60 \mathrm{~min}$ at $37^{\circ} \mathrm{C}$. The samples for estimation were deproteinized by addition of $2 \mathrm{ml}$ of trichlor acetic acid (TCA) to a concentration of $5 \%(\mathrm{w} / \mathrm{v})$ in a centrifuge tube, and spun at 2,500 rpm for $5 \mathrm{~min}$ for deproteinizing and stopping of the reaction. Three milliliter of Ehrlich reagent were added to $1 \mathrm{ml}$ of the supernatant in $20-\mathrm{ml}$ glass tube test. Colorimetry exactly $30 \mathrm{~min}$ after the addition was carried out at $553 \mathrm{~m} \mu$ with a spectrophotometer (Hitachi model 101). The activity of ALAD was expressed as umol of PBG synthesized per milliliter of packed red cells per hour of incubation. The precision of the method was good 


\section{LOW LEAD CONCENTRATION}

with a coefficient of variation of $1.83 \%$ calculated from five determinations on one blood sample of a normal healthy man with ALAD activity in erythrocytes between 1.440 and 1.521 (mean=1.484). Lead concentration in the blood was determined as lead dithizonate after mineralization with $\mathrm{H}_{2} \mathrm{SO}_{4}, \mathrm{HNO}_{3}$, and $\mathrm{HClO}_{4}$ by atomic absorption spectrophotometry ${ }^{8}$ (Hitachi model 208). That is, the blood samples were collected in heparinized 10-ml glass test tubes containing $1 \mathrm{mg}$ sodium heparin. The blood samples were digested by mixture of concentrate nitric acid and concentrate sulphuric acid. The oxidation was completed by hydrogen peroxide. After adjusting the $\mathrm{pH}$ to about 9.8 with concentrate ammonia, the lead was extracted by diphenylthiocarbazone into isobutylmethylketone before measurement.

Two hundred eightyfive air samples from 4 points in Sapporo and 4 points in Otaru were collected by high-volume sampler with glass-fiber (Staplex) from August 1969 to September 1971 in Sapporo and from June 1967 to July 1971 in Otaru, and lead in the working environment of the ceramics company was also determined by an atomic absorption spectrometry.

\section{RESUlts}

Table 1. Values of specific gravity of whole blood, microhematocrit, lead concentration in blood and $\delta$-aminolevulinic acid activity in erythrocytes.

Specific gravity of whole blood

\begin{tabular}{llcccc}
\hline Cities & (Population) & No. & Mean \pm SE & Median & 95\% Upper limit \\
\hline Big city & (above 1,000,000) & 115 & $1.0590 \pm 0.0002$ & 1.0590 & 1.0620 \\
Middle city $(50,000$ up to 200,000) & 57 & $1.0591 \pm 0.0003$ & 1.0590 & $1.0630-{ }^{\dagger}$ \\
Small city $\quad$ (under 50,000) & 31 & $1.0602 \pm 0.0004$ & 1.0610 & $1.0630-$ \\
\hline & Microhematocrit in \% & & \\
\hline Big city & 114 & $48.94 \pm 0.24$ & 48.5 & 54.0 \\
Middle city & 57 & $48.32 \pm 0.40$ & 48.5 & 52.5 \\
Small city & 31 & $49.15 \pm 0.51$ & 49.0 & 53.5
\end{tabular}

Lead concentration in blood in $\mu \mathrm{g} / 100 \mathrm{ml}$

\begin{tabular}{lrrrr}
\hline Big city & 115 & $10.14 \pm 0.31$ & 9.9 & $14.6-\square$ \\
Middle city & 57 & $9.24 \pm 0.33$ & 8.9 & $13.3-\dagger$ \\
Small city & 31 & $8.24 \pm 0.49$ & 7.8 & $12.1-\dagger+$
\end{tabular}

$\delta$-aminolevulinic acid activity in erythrocytes

\begin{tabular}{lrrrr}
\hline Big city & 114 & $1.244 \pm 0.021$ & 1.228 & 1.574 \\
Middle city & 57 & $1.261 \pm 0.032$ & 1.274 & 1.614 \\
Small city & 31 & $1.224 \pm 0.047$ & 1.215 & 1.622 \\
\hline
\end{tabular}

$\dagger, \uparrow+$ : Significant difference at $\mathrm{p}<0.05$ and $\mathrm{p}<0.01$. 


\section{K. SAITO, T. SATO, Y. SATO AND K. NIIZUMA}

Arithmetical means and standard errors (SE), medians and the upper values of $95 \%$ of the distributions in the specific gravity of whole blood, microhematocrit, lead content in the blood and ALAD activity in erythrocytes of the traffic policemen are shown in Table 1. Significant differences among the big city, the middle city and the small city were observed in the specific gravity of whole blood and in lead content in the blood with Student's t-test. The specific gravity of whole blood in the big city showed higher values than those in the small city $(p<0.05)$, and those in the middle city showed higher values than in the small city $(p<0.05)$. Lead concentration of those in the big city showed a significantly higher value
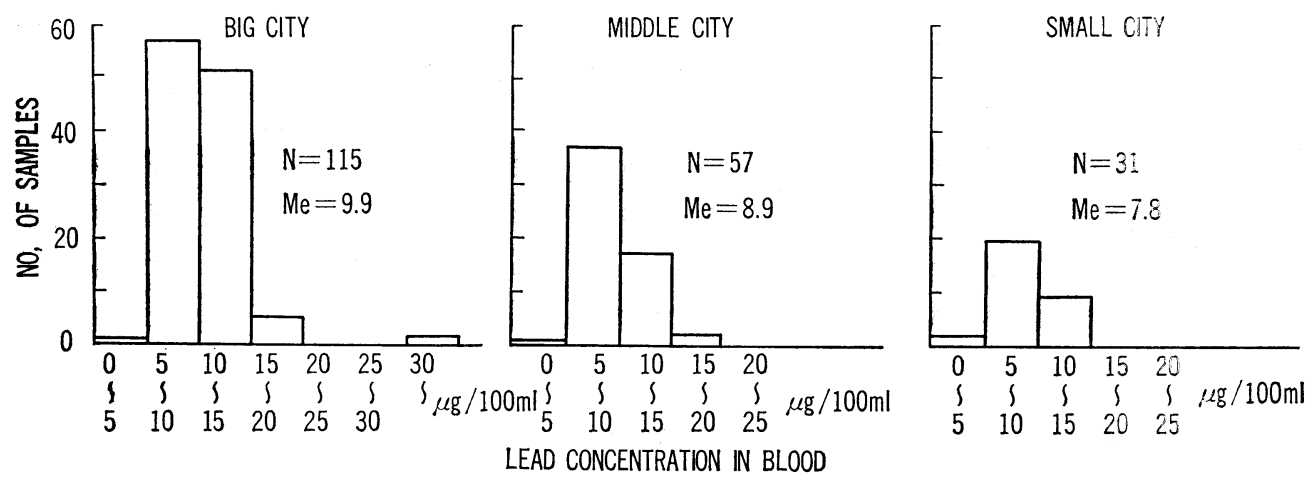

Fig. 1. Distribution of lead content in blood by large in scale of cities; $\mathrm{N}$ : number of samples, Me: median.

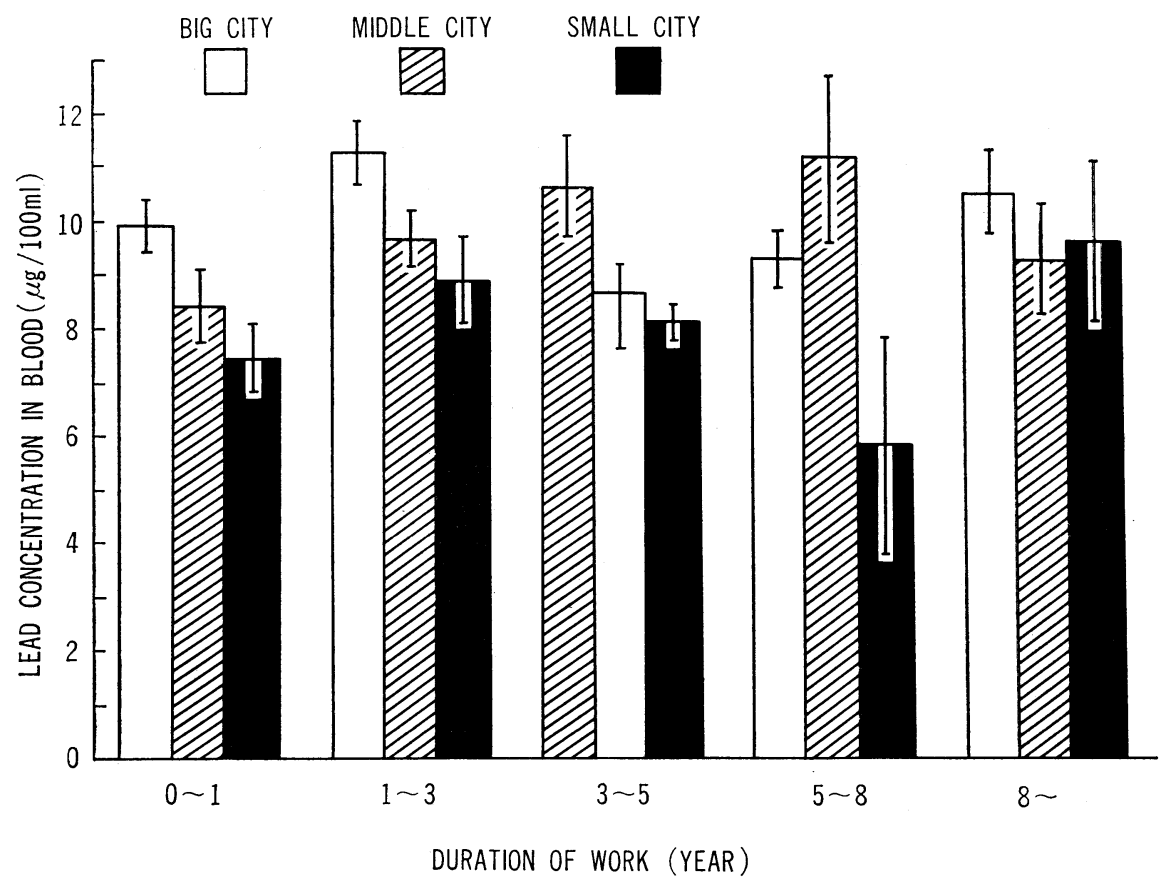

Fig. 2. Variation of lead content in blood by duration of work in traffic policemen on patrol car. 


\section{LOW LEAD CONCENTRATION}

than in the middle city $(\mathrm{p}<0.05)$ and in the small city $(\mathrm{p}<0.01)$, but no significant differences were found in the values of microhematocit and ALAD activity in erythrocytes.

Fig. 1 gives the distributions of lead content in blood. Medians of the examinees in these cities were $9.9 \mu \mathrm{g} / 100 \mathrm{ml}$ in the big city, $8.9 \mu \mathrm{g} / 100 \mathrm{ml}$ in the middle city and $7.8 \mu \mathrm{g} / 100 \mathrm{ml}$ in the small city respetively. These figures seem to be the logarithmic normal distribution, but this can not be exactly stated. Fig. 2 shows the relationship of the duration of their service as traffic policemen to lead content in the blood. Under 5 years of the duration, lead concentration in the blood was higher in the order of the big city, the middle city and the small city, and it was significant between the big city and the middle and the small cities respectively. However, no significantly definite relationship with the period of their service was found in the specific gravity of whole blood, microhematocrit and ALAD activity.

Comparison of the specific gravity of whole blood, hematocrit, lead concentration in the blood and ALAD activity in erythrocytes between the traffic policemen on patrol by car and the workers exposed to inorganic lead dust at the ceramics company is shown in Table 2. Statistically significant difference between both groups was not found in the specific gravity of whole blood, but in hematocrit value, lead concentration and ALAD activity $(p<0.01)$. Lead concentration in the air distributed from 0.18 to $8.96 \mu \mathrm{g} / \mathrm{m}^{3}$ in the cities and from 25.3 to $205.4 \mu \mathrm{g} / \mathrm{m}^{3}$ in the working environment at the ceramics company.

Table 2. Comparison of values between traffic policemen and lead-workers.

\begin{tabular}{lrrrrr}
\multicolumn{1}{c}{ Group } & No. & $\begin{array}{c}\text { Specific gravity } \\
\text { of whole blood }\end{array}$ & $\begin{array}{l}\text { Microhema- } \\
\text { tocrit } \%\end{array}$ & $\begin{array}{c}\text { Pb in blood } \\
\mu \mathrm{g} / 100 \mathrm{ml}\end{array}$ & ALAD \\
\hline Traffic policemen & 203 & $1.0592 \pm 0.0002$ & $48.81 \pm 0.20$ & $9.60 \pm 0.22$ & $1.234 \pm 0.017$ \\
Lead-workers & 19 & $1.0595 \pm 0.0007$ & $46.18 \pm 0.67^{\dagger}$ & $19.50 \pm 1.42^{\dagger}$ & $0.959 \pm 0.073^{\dagger}$ \\
\hline
\end{tabular}

$\dagger$ : Statistically significant difference between traffic policemen and lead-workers by Student's $\mathrm{t}$-test at $\mathrm{p}<0.01$.

Table values are means $\pm \mathrm{SE}$.

Comparison of lead concentration in blood was carried among developed cities like Sapporo, the undeveloped cities like Kuttyan, and the characteristic cities as Otaru and Chitose. Lead content in the blood of traffic policemen on patrol by car in Sapporo showed $10.14 \mu \mathrm{g} / 100 \mathrm{ml}, 11.39 \mu \mathrm{g} / 100 \mathrm{ml}$ in Otaru, and so forth (Table 3).

The correlations between ALAD activity in erythrocytes and lead concentration in blood of traffic policemen and lead workers were found at $\hat{Y}=1.346-0.011 X$ : $r=-0.144 \quad(p<0.05)$, and at $\hat{Y}=1.818-0.044 X: r=-0.851 \quad(p<0.01)$ respectively. Significant difference between these two correlation coefficients was observed $\left(\frac{Z_{r_{1}}-Z_{r_{2}}}{\sigma_{d}}=4.646>2\right)$. 


\section{K. SAITO, T. SATO, Y. SATO AND K. NIIZUMA}

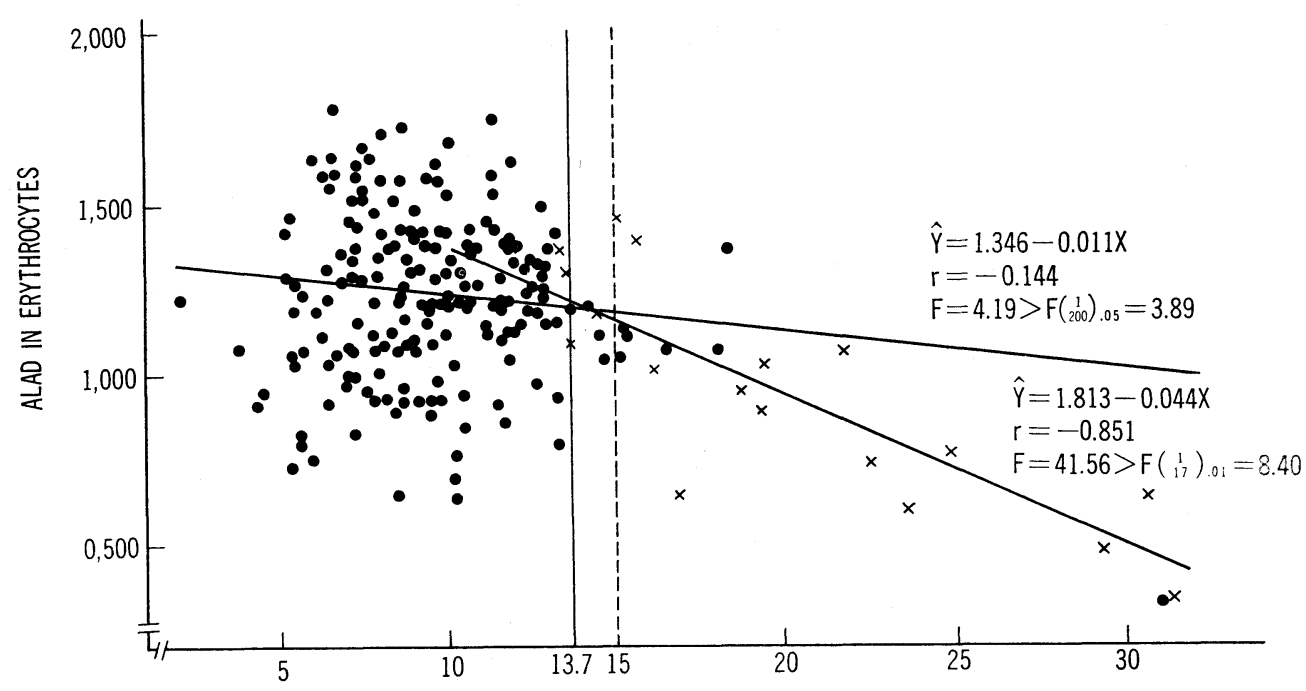

LEAD CONCENTRATION IN $\mu \mathrm{g}$ PER $100 \mathrm{ml}$ OF BLOOD

Fig. 3. Correlation between lead concentration in blood and ALAD activity in erythrocytes in 202 traffic policemen (dots), and 19 lead-workers (black marks). The perpendicular line of $13.7 \mu \mathrm{g} \mathrm{Pb} / 100 \mathrm{ml}$ of blood on abscissa presents $95 \%$ upper limit of traffic policemen, and that of 15.0 corresponds to upper normal limit of lead in blood.

Then, when the values of the lead-workers at the ceramics company were added to those of the traffic policemen, the correlation coefficient was -0.393 : $\hat{Y}=1.455-0.023 X(p<0.01)$ (Fig. 3). However, any correlation between lead concentration in blood and ALAD was not observed under $15 \mu \mathrm{g}$ pb per $100 \mathrm{ml}$ of blood in traffic policemen.

Table 3. Blood lead values by cities in Hokkaido.

\begin{tabular}{lrrrc}
\hline \multicolumn{1}{c}{ Cities } & Population ${ }^{\dagger}$ & No. & Mean & Range \\
\hline Sapporo & $1,010,123$ & 115 & 10.14 & $31.1-4.5$ \\
Otaru & 191,856 & 9 & 11.39 & $16.5-6.6$ \\
Muroran & 162,059 & 12 & 8.01 & $10.7-5.7$ \\
Tomakomai & 101,573 & 14 & 8.16 & $10.8-4.3$ \\
Iwamizawa & 68,712 & 7 & 8.71 & $10.8-6.4$ \\
Ebetsu & 63,762 & 4 & 9.58 & $13.2-6.7$ \\
Chitose & 56,118 & 4 & 11.08 & $12.8-8.9$ \\
Datemonbetsu & 29,552 & 4 & 9.30 & $11.9-7.3$ \\
Kuttyan & 19,146 & 4 & 5.75 & $9.0-2.0$ \\
\hline
\end{tabular}

t: Population by census on October 1, 1970.

Values are $\mathrm{Pb}$ in $\mu \mathrm{g} / 100 \mathrm{ml}$ of blood. 


\section{LOW LEAD CONCENTRATION}

\section{Discussion}

In 1960 Kehoe $^{9)}$ showed the concentration of lead in the atmosphere of various cities in the United States and in the location of rural, residential and industrial districts in Cincinati. As a result, lead was more in the order of industrial (3.0$\left.4.1 \mu \mathrm{g} / \mathrm{m}^{3}\right)$, residential $\left(1.6-2.5 \mu \mathrm{g} / \mathrm{m}^{3}\right)$ and $\operatorname{rural}\left(0.8-1.3 \mu \mathrm{g} / \mathrm{m}^{3}\right)$. Nakagawa et al. ${ }^{10)}$ reported on the almost same results in Tokyo. In this paper, also, specific gravity of whole blood and lead concentration in blood of traffic policemen were shown in proportion to large in scale of cities in Hokkaido. The lead content in blood was proportionate to the scale of cities in each period of the service on patrol by car less than for 5 years, which may be thought to be much concerned with the amount of lead absorbed into human body. Goldwater et al. ${ }^{11)}$ reported that the mean value of 801 samples which were collected from 16 countries of the world was $17 \mu \mathrm{g}$ of lead per $100 \mathrm{ml}$ of blood with a standard deviation of 11 , and that a "normal" range of lead in the blood was suggested from 15 to $40 \mu \mathrm{g}$ of lead per $100 \mathrm{ml}$ of blood. On the other hand, normal level of lead in blood is the range from 10 to $40 \mu \mathrm{g}$ pb per $100 \mathrm{ml}$ of blood by Kehoe ${ }^{12)}$. Our data of traffic policemen in this paper showed the value of $9.62 \pm 0.17 \mu \mathrm{g} \mathrm{pb} / 100 \mathrm{ml}$ in blood, so this value is undoubtedly a normal range judging from the about range. Haeger Aronsen, et al.$^{6)}$ also reported $12.3 \pm 0.78 \mu \mathrm{g} / \mathrm{dl}$ on traffic workers at Lund in Sweden which is significantly higher than that of Hokkaido $(p<0.01)$. The average lead concentrations in blood of inhabitants in Tokyo ${ }^{13)}$, Hiroshima and Kure ${ }^{14)}$ were $13.50,16.04$ and $16.25 \mu \mathrm{g} / 100 \mathrm{~g}$ of blood respectively, and those of traffic policemen in Sapporo was $10.17 \mu \mathrm{g} / 100 \mathrm{ml}$, and Nagasaki's ${ }^{15)}$ was $17.47 \mu \mathrm{g} / 100 \mathrm{ml}$ which is significantly higher than that of Lund in Sweden $(p<0.01)$. In Japan, the leadlevels in Nagasaki's was higher than that of Sapporo's $(p<0.01)$. ALAD showed also the same tendency among Sapporo, Nagasaki and Lund in Sweden.

In order to confirm the fact that lead content in the blood relate to the amount of atmospheric lead as Goldsmith et al. ${ }^{3)}$ made clear, lead-workers who work in an environment with a higher concentration of lead than atmosphere, were compared to the traffic policemen. The concentration of lead in the working environment distributed from 25.3 to $205.4 \mu \mathrm{g} / \mathrm{m}^{3}$ and the atmospheric lead ranged from 0.18 to $8.96 \mu \mathrm{g} / \mathrm{m}^{3}$. Definite difference of lead content in blood between two groups was observed. From the above relationship between the difference of atmospheric environment and lead concentration in the blood of examinees, it was revealed that atmospheric lead plays an important role in increase of lead content in blood even with a low concentration of lead in the air at less than $10 \mu \mathrm{g} / \mathrm{m}^{3}$. Also, difference which was observed among the cities may take part above supposition. It is possible to understand that Sapporo is characteristic with many automobiles on the streets, Otaru is famous for its' sloping roads, Chitose has an airport, and Kuttyan is not a modernized area but an agricultural area surrounded by mountains, and that the differences of these enviromental condition appeared in the values. 


\section{K. SAITO, T. SATO, Y. SATO AND K. NIIZUMA}

There is a question whether ALAD activity in erythrocytes belows in the normal range of lead content in blood. Some investigators ${ }^{4,5,16)}$ reported that there was a negative correlation between lead content and ALAD at somewhat high lead concentration in blood or lead poisoning. Then, Herenberg $e$ al ${ }^{4}{ }^{4}$ ) showed the fact that there was the correlation at low lead concentration in blood of normal medical students, never exposed occupationally to lead, but 25 lead contents in blood of 26 students ranged from approximately 4.0 to $17.0 \mu \mathrm{g} / 100 \mathrm{ml}$. Only one of them was approximately $33.0 \mu \mathrm{g} / 100 \mathrm{ml}$. It seems that the negative correlation occured by depending on the remote value of $33.0 \mu \mathrm{g} / 100 \mathrm{ml}$, and number of samples is very few. Nakao et $a .^{16)}$ and Haeger Aronsen ${ }^{4}$ had not fully discussed about the correlation between the lead content in blood and ALAD at low lead concentration in blood of normal adults. Our data may answer to that question, because among the values of total traffic policemen ranged from 2.0 to 31.1 (mean 9.6) $\mu \mathrm{g} \mathrm{Pb}$ and lead-workers ranged from 14.3 to 31.2 (mean 19.5) $\mu \mathrm{g} \mathrm{Pb}$ per $100 \mathrm{ml}$ of blood, negative correlations between lead concentration in blood and ALAD activity were observed respectively, but any correlation was not shown under 15.0 $\mu \mathrm{g} \mathrm{Pb}$ per $100 \mathrm{ml}$ of blood.

On the contrary, rather positive correlation which is $r=0.143(p<0.05)$ was found among the value under $13.7 \mu \mathrm{g} \mathrm{Pb}$ per $100 \mathrm{ml}$ of blood which was $95 \%$ upper limit of traffic policemen. The authors think that the value of $15.0 \mu \mathrm{g} \mathrm{Pb}$ per 100 $\mathrm{ml}$ of blood is the upper limit of normal lead concentration in blood. It may be further assumed that the lead in blood under $13.7 \mu \mathrm{g}$ per $100 \mathrm{ml}$ of blood may promote ALAD activity.

It is very difficult to define how amounts of lead concentration in blood are enough to have effect and that the proportion of ALAD to changes within normal range of blood levels at low lead concettration has any significance in the human body. Relatively small amounts of lead are present in the cytoplasm and mitochondria. Although it is suggested that soft-tissue lead accumulates in the intranuclear inclusion body, thereby sparing toxic injury to cytoplasmic organelles ${ }^{17}$, such effect of low lead levels in blood and subclinical lead poisoning have not become clear.

\section{ConcLusion}

Two hundred three traffic policemen on patrol by car and 19 lead-workers were measured on specific gravity of whole blood, microhematocrit and lead content in blood and ALAD activity in erythrocytes. The results obtained as follows:

1. Significant differences among the large in scale cities were observed in specific gravity of whole blood and lead concentration in blood.

2. Lead concentration in blood and ALAD activity in erythrocytes of leadworkers were significantly higher than that of traffic policemen on patrol by car.

3. It seems that lead concentration in blood is higher in a developed city and 


\section{LOW LEAD CONCENTRATION}

in such characteristic cities where they have sloping roads or an airport than that of undeveloped cities.

4. The correlations beween ALAD activity in erythrocytes and lead concentration in blood were found in the traffic policemen and the lead worker, but among the samples under $15.0 \mu \mathrm{g} \mathrm{Pb}$ per $100 \mathrm{ml}$ of blood in traffic policemen was not observed any correlation.

This paper was partially presented at the annual meeting of the 31st Japanese Society of Public Health, Sapporo, October 25 to 27, 1972.

\section{REFERENCES}

1) Lazrus, A. L., Lorange, E. and Lodge, J. P. (1970). Environ. Sci. Technol., 4, 55.

2) Shimamura, H., Yamaguchi, T. and Shimizu, K. (1971). Jidosha Haigasu Kogai, (Public nuisance on automobile exhaust gases) p. 44. Kagakukogyosha, Tokyo. (in Japanese)

3) Goldsmith, J. R. and Hexter, A.C. (1967). Science, 158, 132.

4) Herenberg, S. and Nikkanen, J. (1970). Lancet, 1, 63.

5) Herenberg, S., Nikkanen, J., Mellin, G. and Lilius, H. (1970). Arch. Environ. Health, 21, 140.

6) Haeger-Aronsen, B., Abdulla, M. and Fristedt, B.I. (1971). Arch. Environ. Health, 23, 440.

7) Granick, S. and Mauzerall, D. (1958). J. Biol. Chem., 232, 1119.

8) Yagyu, H., Hashizume, R., Akiyama, K., Takahashi, R., Ikeda, S., Nagasaki, M., Shimbo, S., Udo, R. and Kizuka, T. (1970). Annu. Rep. Tokyo Metropolitan Res. Lab. Public Health, 22, 187. (in Japanese)

9) Kehoe, R. A. (1961). J. Roy. Inst. Public Health, 24, 81.

10) Nakagawa, K., Nagasaki, M., Shinpo, S., Udo, R., Kizuka, T., Yagyu, H., Akiyama, K., Takahashi, T., Nagashima, C., Fujiya, K., Ogasawara, K., Shimoda, S. and Bushimata, K. (1972). Jap. J. Public Health, 19, 418. (in Japanese)

11) Goldwater, L. J. and Hoover, A. W. (1967). Arch. Environ. Health, 15, 60.

12) Kehoe, R. A. (1972). J. Occup. Med., 14, 390.

13) Nakagawa, K., Nagasaki, M., Shinpo, S., Udo, R., Kizuka, T., Yagyu, H., Akiyama, K., Takahashi, T., Okubo, N., Kano, G., Ogasawara, K., Shimoda, S. and Bushimata, K. (1971). Jap. J. Public Health, 18, 476. (in Japanese)

14) Hasegawa, H. (1972). Jap. J. Hyg., 27, 124. (in Japanese)

15) Taira, K. and Miura, H. (1972). Jap. J. Hyg., 27, 125. (in Japanese)

16) Nakao, K., Wada, O. and Yano, Y. (1968). Clin. Chim. Acta, 19, 319.

17) Goyer, R. A., Leonard, D. L., Moorc, J.F., Rhyne, B. and Krigman, M. R. (1970). Arch. Environ. Health, 20, 705. 